Светозар Бошков

Оригиналан научни рад

Универзитет у Новом Саду

Филозофски факултет

Одсек за историју

svetozarboskov@hotmail.com

\title{
КОНСТАНТИН ВЕЛИКИ У СРПСКОЈ ИСТОРИОГРАФИЈИ ХІХ ВЕКА
}

Сажетак: Многа историографска дела која су се појавила у XIX веку имају за тему античку историју. У то време почело је и систематско проучавање античке историје код Срба. У овом раду приказаћемо најважније радове из XIX века која говоре о Константину Великом и његовом добу, а посебну пажњу посветићемо оним делима која су се користила у српским школама у то време - уџбеницима историје, историјским читанкама и приручницима.

Кључне речи: Константин Велики, историографија, историја, антика, уџбеници.

У српској историографији ХІХ века појавило се неколико монографија које су посвећене проучавању античког периода. То су углавном биле Историје света које су настале из потребе да ученици у српским школама, пре свега гимназијама, уче из књига на српском језику. ${ }^{1}$ С обзиром да је у њима описан период од најстаријих времена, велики простор био је посвећен и античком периоду, а незаобилазан период било је и време Константина Великог (306-337) и доношење Миланског едикта 313. године, који се данас обележава као један од најважнијих периода у хришћанском свету. Овде ћемо представити на који начин је српски народ y XIX веку био упознат са овим важним периодом римске и светске историје.

Средином XIX века појавило се неколико Историја света које у свом садржају неизоставно имају поглавље посвећено Константину Великом и Миланском едикту. Прву књигу коју ћемо представити написао је Стојан Бошковић 1866. године. ${ }^{2}$ Он је Константина Великог описао као мудрог и храброг цара који је у немирима и ратовима, који су избили после повлачења цара Диоклецијана са власти, преузео власт уз помоћ хришћана. ${ }^{3}$ Према подацима које нам оставља Бошковић,

${ }^{1}$ С. Бошков, Античка прошлост у Историји света Александра Сандића, Истраживања 21, Нови Сад 2010, 55.

${ }^{2}$ С. Бошковић, Историја света за народ и школу у четири књиге, књига 1, Историја старог века, Београд 1866.

${ }^{3}$ С. Бошковић, Историја света, 361 . 
пресудан моменат догодио се 312. године када му се на небу указао крст на којем је било исписано С овим ћеш победити. На основу овог податка можемо да приметимо

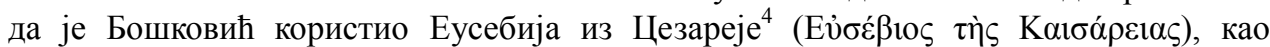
историјски извор иако то не наводи. Бошковић посебне заслуге приписује и његовој мајци, царици Јелени, која је била хришћанка, а управо је то навело многе хришћане да приступе његовој војсци. ${ }^{5}$ Због помоћи коју су му пружили приликом преузимања власти, Константин је прогласио слободу вероисповести за све хришћане, а касније је и сам прихватио хришћанство као своју веру. ${ }^{6}$ Бошковић још напомиње да је Константин основао нови град који је касније постао центар Византије не наводећи годину оснивања града нити тачно место где је град основан. ${ }^{7}$ На основу ових података примећујемо да С. Бошковић не поклања превише пажње периоду позног римског царства, јер видимо да су многи важни подаци изостављени у овом поглављу. На пример, он уопште не спомиње ко су били супарници Константина Великог око преузимања власти, нити која је то одлучујућа битка у којој је Константин победио 312. године. Пресудан моменат за њега је истицање улоге коју су имали хришћани у Константиновој борби за преузимање власти и он то представља као политички мудру одлуку коју је донео Константин. Међутим, необично је да ниједном није поменуо доношење Миланског едикта као прекретнице у слободи вероисповести хришћана на територији римске државе. Бошковић поглављем о Константину Великом завршава излагање историје Римског царства и само у неколико реченица помиње сеобу народа и пад Западног римског царства 476. године. ${ }^{8}$

После три године у Новом Саду се појавила нова Историја света коју је написао Александар Сандић ${ }^{9}$ у којој такође налазимо неколико података о Константину Великом. И у њој преовлађују подаци који говоре о Константиновом односу према хришћанима, али Сандић има другачији приступ у односу на Бошковића. Он не пише о улози хришћана у преузимању власти као Бошковић, већ говори о заслугама Константина да се дозволи слобода вероисповести за хришћане и каже да је коначно, после два века прогона: „за изара Константина хришћанство буде вера државна. “10У томе посебно истиче и улогу његове мајке Јелене. Међутим, он то ради на крајње необичан начин ређајући Константинове заслуге без много информација, изостављајући важне личности које су учествовале у тим историјским догађајима, али и године. На пример, у једном малом издвојеном пасусу, без хронолошког реда, пише о легенди коју нам је записао већ помињани Еусебије из Цезареје и само каже да се у једном војном походу цару Константину на небу, односно облаку, јавио крст са натписом $c$ овим ћеш победити ${ }^{11}$ без икаквих објашњења о којој бици се ради и против кога је ратовао Константин. Ко не зна да се

${ }^{4}$ Euseb.Vit. Const I 28-29.

${ }^{5}$ С. Бошковић, Историја света, 361.

${ }^{6} \mathrm{C}$. Бошковић, Историја света, 361-362.

${ }^{7}$ С. Бошковић, Историја света, 362.

${ }^{8}$ С. Бошковић, Историја света, 362-363.

${ }^{9}$ А. Сандић, Историја света, књига 1, Стари век, Нови Сад 1869

${ }^{10} \mathrm{~A}$. Сандић, Историја света, 250.

${ }^{11}$ А. Сандић, Историја света, 244. 
овај податак односи на битку код Мулвијског моста која се одиграла 312. године и где је Константин победио Максенција не може да разуме ове податке. С обзиром да пре тога Сандић пише о Константиновим напорима и заслугама за организовање Првог васељенског сабора у Никеји 325. године, ${ }^{12}$ изгледа да му и није била намера да се посебно удубљује у ову проблематику, јер је очигледно хтео да се једино истакне Константинова улога у дозвољавању слободе вероисповести хришћанима на територији римског царства. ${ }^{13}$ Вероватно из тог разлога код Сандића не налазимо ни податке о 313. години и Миланском едикту. Дакле, пише да је Константин прогласио хришћанску веру за државну, али не наводи детаље како је до тога дошло. Нема помена ни Лицинија ни његове улоге и односа према хришћанима.

За разлику од Бошковића, Сандић пише и о административној подели царства на, како он каже, 13 дијецеза и 116 провинција, чиме је наставио реформе које је започео Диоклецијан. Ова административна подела условила је и оснивање новог града Константинопоља за који Сандић каже да је Нови Рим. Једина негативна ствар коју је урадио Константин је, према мишљењу Сандића, повећање пореза на штету народа. ${ }^{14}$

Трећа књига коју ћемо овде представити, а која описује Константина Великог и његово доба, је Историја старог века Милоша Зечевића која се појавила 1896. године. ${ }^{15}$ И у овој књизи хришћанство има пресудну улогу у доласку Константина Великог на власт. На почетку поглавља које говори о Константину сазнајемо да је рођен у Нишу, што до сад нисмо могли да прочитамо у некој књизи из XIX века. Зечевић своје излагање почиње описом доласка Константина на власт уз помоћ војске која га је у Британији прогласила за цара, а затим описује борбу за власт над западним делом Римског царства која је завршена битком код Мулвијског моста 312. године где је Константин Велики победио Максенција, који се током битке удавио у Тибру. ${ }^{16}$ Зечевић даље описује борбу Константина Великог за превласт на територији целог царства. На истоку су му противници били Лициније и Максимин Даја. Зечевић пише да је Константин у овој борби за превласт на истоку одабрао за савезника Лицинија, а да би учврстио савез дао му је руку своје сестре. ${ }^{17}$ Занимљиво је да Зечевић истиче ово венчање као разлог чврстих веза Константина Великог и Лицинија и да притом уопште не помиње Милански едикт који су издали заједно 313. године. Исте године Лициније је поразио Максимина који убрзо после битке умире. Две године касније долази до битке између Константина Великог и Лицинија недалеко од Сирмијума на реци Сави у којој Константин односи победу. ${ }^{18}$ Борба између њих није тада завршена, а Зечевић је ову борбу представио као борбу између хришћана, који су били на страни Константна Великог, и оних који су подржавали Лицинија, а који су веровали у старе римске богове. Вероватно да би

\footnotetext{
${ }^{12}$ А. Сандић, Историја света, 243.

${ }^{13}$ А. Сандић, Историја света, 243.

${ }^{14}$ А. Сандић, Историја света, 243-244.

${ }^{15}$ М. Зечевић, Историја старог века, преглед за вишу наставу, Београд 1896.

${ }^{16}$ М. Зечевић, Историја старог века, 299.

${ }^{17}$ М. Зечевић, Историја старог века, 299.

${ }^{18} \mathrm{M}$. Зечевић, Историја старог века, 300.
} 
истакао тежину и важност ове борбе, између хришћана и оних који су веровали у старе римске богове, Зечевић тек после ове битке описује легенду према којој се Константину указао крст на небу на којем је било записано под овим ћеш знаком победити, ${ }^{19}$ иако се према изворима све то догодило још пре битке код Мулвијског моста када се сукобио са Максенцијем. Одлучујућа битка између Константина и Лицинија одиграла се 324. године код Хадријанопоља. ${ }^{20}$ После описа победе Константина над Лицинијем и Зечевић, као и сви претходни аутори, описује оснивање града Константинопоља. ${ }^{21}$ Као и Сандић и Зечевић описује административне реформе које је спровео Константин Велики у Римском царству. Подаци које износи се незнатно разликују од Сандићевих и он каже да је Константин изделио државу, по угледу на Диоклецијана, на 4 префектуре, 14 дијецеза и скоро 120 провинција. Државом је управљао цар уз саветодавну помоћ Царског савета који Зечевић назива свети конзисториј (sacrum consistorium). ${ }^{22}$

На крају, Зечевић даје и негативан коментар о Константиновој владавини због реформи које је извршио оног тренутка када је почео да влада самостално. Пре свега, оптужује га да држава сада личи на источњачке деспотије и да и најмањим дворским чиновницима додељује титуле које, како он наводи: „...једва можемо у демократском језику намем наћи подесних речи ради превода, као од прилике светли, угледни, ванредни, најсјајнији, најплеменитији, најсавршенији итд. (illustris, spectabilis, egregius, clarissimus, nobilissimus, perfectissimus etc.)“. ${ }^{23}$ Даље у тексту описује и лошу Константинову страну наводећи да је одговоран за смрт таста, шурака, зета, жене, нећака и сина. Због свега тога, он Константина пореди са персијским владаром Артаксерксом. Попут Сандића, највише му замера подизање пореза за издржавање великог чиновничког апарата. Ипак, како каже Зечевић, све то није спречило хришћане да га уврсте, заједно са мајком Јеленом, у свеце због издавања Миланског едикта којим се хришћанима дозвољава да слободно исповедају своју веру. ${ }^{24}$

У последњој књизи коју ћемо овде представити, а коју је написао О. Варга, ${ }^{25}$ Константин је представљен у два одвојена поглавља. У првом поглављу под насловом Константин Велики (323-337) аутор говори о уређењу римске државе током његове власти. Као најважније Константиново дело аутор наводи оснивање новог града Константинопоља који се налазио на идеалном географском положају, између истока и запада и који је својим раскошем, палатама и јавним грађевинама подсећао на Рим. Административна подела царства на четири префектуре, дијецезе и провинције коју је извршио Диоклецијан остала је на снази и за време Констанина. ${ }^{26}$

\footnotetext{
${ }^{19}$ М. Зечевић, Историја старог века, 300.

${ }^{20}$ Данашњи град Једрене (Едирне) у Турској.

${ }^{21}$ М. Зечевић, Историја старог века, 300.

${ }^{22}$ М. Зечевић, Историја старог века, 301.

${ }^{23}$ М. Зечевић, Историја старог века, 301.

${ }^{24} \mathrm{M}$. Зечевић, Историја старог века, 301

${ }^{25} \mathrm{O}$. Варга, Историја света по наставном плану и упутству за средње школе, Прва свеска, стари век Нови Сад 1898.

${ }^{26}$ О. Варга, Историја света, 183.
} 
У овом поглављу налазимо и један податак који се није налазио у осталим књигама. Реч је о појму imperator. О. Варга пише да се под тим појмом више не означава војсковођа као у доба републике, него да је у време позног римског царства, тачније у време Константина Великог, то означавало државног заповедника, владара, односно цара у савременом смислу. Варга каже: „да он више није први грађанин у држави, него господар државе, ласкање га изнајпре назива наш господар, наш цар, а касније улази та реч и у законе.“27

Још један нови податак налазимо код Варге. Он описује промене у организацији војске које је започео Диоклецијан, а завршио Константин. Војска је сада била подељена на две велике групе, пограничне и мобилне јединице, или како их назива Варга дворска и крајишка војска. Он сматра да су разлике у финансирању ових војних јединица, с обзиром да су крајишници тј. пограничне трупе, биле слабије плаћене, и то што су Германи сада били делом припадници ових пограничних трупа, условило да су они лоше чували границе. Чак ни пола милиона граничних војника није успело да сачува границе царства од упада варвара. ${ }^{28}$ Издржавање овако велике војске и дворских чиновника новог града подстакло је Константина на повећање пореза што је једина мера коју је донео Константин, а коју Варга помиње у негативном контексту.

Варга о Константину говори у још једном поглављу под насловом Хришћанство и римско ичарство. У овом поглављу пише о хришћанству и описује, како он каже, легенду о борби Константина против Максенција. Поред већ споменутог догађаја код претходних аутора да је пре битке са Максенцијем на небу видео крст са исписаним речима овим знаком победићеш, код Варге се налази и податак да је Константин уснио сан пред битку у ком му се јавио Спаситељ који му је рекао да стави нова знамења на заставу и да ће с тим знаком победити. ${ }^{29}$ Први пут видимо да се појављује овај податак који нам је забележио Лактанције. ${ }^{30}$ Последњи догађај који нам описује О. Варга је сазивање Првог васељенског сабора у Никеји 325. године с циљем, како каже Варга: „...да престану распре, које у то доба беху наступиле у новој вери те су јединство угрозиле.“1

Видели смо да период владавине Константина Великог чини обавезни део у монографијама које су се појавиле у XIX веку. Иако је приметно да постоје разлике у подацима које проналазимо у монографијама које су се појавиле средином XIX века и оних које су се појавиле на крају XIX века, као и да постоји разлика у приступу и представљању политичке и религијске улоге коју је имао Константин Велики, заједничка карактеристика им је да Константина Великог описују као владара који је хришћанима дозволио слободу вероисповести. Међутим, интересантно је да ниједан од наведених аутора не помиње конкретно Милански едикт из 313. године, осим

\footnotetext{
${ }^{27}$ О. Варга, Историја света, 183 .

${ }^{28} \mathrm{O}$. Варга, Историја света, 184.

${ }^{29} \mathrm{O}$. Варга, Историја света, 188

${ }^{30}$ Lact, De mort. pers. XLIV 1-6.

${ }^{31} \mathrm{O}$. Варга, Историја света, 188.
} 
Зечевића који га узгред спомиње без податка када је донет, и није до краја јасно зашто овом едикту о толеранцији, који су склопили Константин Велики и Лициније, није посвећена већа пажња. Већина података, које проналазимо у монографијама у XIX веку, налазе се и у савременим уџбеницима и монографијама, попут оснивања Константинопоља, ${ }^{32}$ или битке код Мулвијског моста, ${ }^{33}$ али сваки од њих обавезно спомиње и Милански едикт из 313. године ${ }^{34}$ као едикт о толеранцији којим је хришћанима дозвољено јавно исповедање вере, а чиме је хришћанство у правном смислу изједначено са старом римском религијом. Било да су политички интереси или религија и веровање утицали на одлуке Константина Великог он ће у хришћанском свету и уопште у историји бити упамћен као први владар који је дозволио хришћанима слободу вероисповести.

\section{Извори и литература:}

Бошков, Светозар, Античка прошлост у Историји света Александра Сандића, Истраживања 21, Нови Сад 2010, 55-63.

Бошковић, Стојан, Историја света за народ и школу у четири књиге, књига прва, историја старог века, Београд 1866.

Варга,Отон, Историја света по наставном плану и упутству за средње школе, Прва свеска, стари век, Нови Сад 1898.

Eusebius, Life of Constantine. Trans. Averil Cameron and Stuart G. Hall, Oxford 1999.

Зечевић, Милош, Историја старог века, преглед за вишу наставу, Београд 1896.

Laktanz, De mortibus persecutorum - Die Todesarten der Verfolger. Lat./dt., übersetzt und eingeleitet von Alfons Städele, Turnhout 2003 (Fontes Christiani 43).

Машкин, Николај Александрович, История древнего Рима, Ленинград 1947. [N. А. Maškin, Istorija starog Rima, Beograd 2002.]

Мирковић, Мирослава, Римска држава у доба приничиата и домината (27. Пре Хр. - 337. Н. e.). Од Августа до Константина, Београд 2003.

Обрадовић, Мирко, Историја 1, уџбеник за први разред гимназије, Београд 2012.

Сандић, Александар, Историја света, књига 1, Стари век, Нови Сад 1869.

\footnotetext{
${ }^{32}$ М. Обрадовић, Историја 1, уџбеник за први разред гимназије, Београд 2012, 247; М. Мирковић, Римска држава у доба принципата и домината (27. пре Хр. - 337. н. е.), 195; N. A. Maškin, Istorija starog Rima, Beograd 2002, 541-542.

${ }^{33}$ М. Обрадовић, Историја 1,246, 254; М. Мирковић, Римска држава у доба принципата и домината (27. nре Xp. - 337. н. е.), 186; N. A. Maškin, Istorija starog Rima, 537.

${ }^{34}$ М. Обрадовић, Историја 1, 254; М. Мирковић, Римска држава у доба принщипата и домината (27. пре Xp. -337. н. е.), 186-187, 190; N. A. Maškin, Istorija starog Rima, 538.
} 


\title{
CONSTANTINE THE GREAT IN SERBIAN $19^{\text {th }}$ CENTURY HISTORIOGRAPHY
}

\begin{abstract}
Summary
Numerous historiographic works which appeared in the $19^{\text {th }}$ century deal with ancient history. This is the same time that Serbs embarked on systematic studying of ancient history. This paper will present the most important $19^{\text {th }}$ century works which talk about Constantine the Great and his era, and special attention will be paid to the works used in Serbian schools at the time - history textbooks, history readers and reference books.
\end{abstract}

Keywords: Constantine the Great, historiography, history, Antiquity, textbooks. 